\title{
COLD PRECIPITABLE HAEMAGGLUTINATING FACTOR IN SERUM FROM PATIENTS WITH RHEUMATOID ARTHRITIS
}

\author{
BY \\ NANNA SVARTZ AND KARL SCHLOSSMANN \\ From the King Gustaf V Research Institute and the Medical Department of the Karolinska Hospital, Stockholm
}

(RECEIVED FOR PUBLICATION FEBRUARY 21, 1955)

The agglutination test with sensitized sheep erythrocytes, first described by Meyer (1922) and rediscovered by Waaler (1940), and by Rose and others (1948), has attracted increasing interest. Since 1948 the present authors have been making various types of investigations into the test in question (Svartz, 1952). The correlation between the haemagglutinating serum factor and rheumatoid arthritis is extremely interesting in view of our observations that this factor is a component present in almost all specimens of blood sera from patients suffering from this disease. Joint fluid from patients suffering from rheumatoid arthritis gave the same results as serum (Svartz and Schlossmann, 1950). Cortisone and ACTH have no-or only a very slight-influence on the test (Svartz, 1950) (Table I).

It was shown with ever-increasing clarity that not infrequently the reaction turned out to be positive in other diseases besides rheumatoid arthritis (Svartz and Schlossmann, 1952). Next to rheumatoid arthritis, lupus erythematosus disseminatus is the disease that has given the largest number of positive reactions. In addition, other "collagen diseases" (such as scleroderma, dermatomyositis, and periarteritis nodosa) give with relative frequency a positive haemagglutination test. The test is usually negative in ankylosing spondylitis, and the same is true of rheumatic fever, but here a slightly positive test is sometimes recorded. Septic arthritis and tuberculous arthritis showed negative results in our series.

From the theoretical as well as from the practical point of view, it is important to keep in mind that the reaction is occasionally positive in disorders other than collagen diseases, such as diseases of the liver, and myeloma.

Manifestly, therefore, it was highly desirable to try to make the reaction more specific in regard to rheumatoid arthritis. Since earlier observations had shown that the haemagglutinating factor accompanies the globulin fraction, it seemed important to find out whether different types of fractionation of serum proteins could throw a clearer light on the degree of specificity of the reaction. The Cohn

TABLE I

HAEMAGGLUTINATION TEST ON SERUM FROM RHEUMATOID ARTHRITIS BEFORE AND AFTER TREATMENT WITH CORTISONE IN A MALE PATIENT

\begin{tabular}{|c|c|c|c|c|c|c|c|c|c|c|c|c|c|c|c|c|}
\hline \multirow{2}{*}{ Date } & \multirow{2}{*}{\multicolumn{2}{|c|}{ Stage of Treatment }} & & & & \multicolumn{10}{|c|}{ Dilution } & \multirow{2}{*}{ Titre } \\
\hline & & & $1: 4$ & $1: 8$ & $1: 16$ & $1: 32$ & $1: 64$ & $1: 128$ & $1: 256$ & $1: 512$ & $1: 1,024$ & $1: 2,048$ & $1: 4,096$ & $1: 8,192$ & & \\
\hline 29.3 .50 & Before treatment wi & Cortone & 4 & 4 & 3 & 3 & 2 & 2 & 2 & 1 & 1 & 1 & 1 & 0 & 0 & 4,096 \\
\hline 6.4 .50 & Before treatment & $\ldots$ & 3 & 3 & 3 & 3 & 2 & 2 & 2 & 2 & 2 & 1 & 1 & 1 & 0 & 8,192 \\
\hline 11.4 .50 & Immediately before & reatment & 3 & 3 & 3 & 2 & 2 & 2 & 2 & 2 & 1 & 1 & 1 & 0 & 0 & 4,096 \\
\hline 18.4 .50 & During treatment & $\cdots$ & 4 & 4 & 3 & 3 & 2 & 2 & 1 & 1 & 1 & 1 & 1 & 1 & 0 & 8,192 \\
\hline 24.4 .50 & During treatment & $\cdots$ & 3 & 3 & 3 & 3 & 3 & 2 & 2 & 2 & 1 & 1 & 1 & 1 & 0 & 8,192 \\
\hline 26.4 .50 & During treatment & $\cdots$ & 4 & 4 & 3 & 3 & 3 & 3 & 2 & 2 & 1 & 1 & 1 & 1 & 0 & 8,192 \\
\hline 29.4 .50 & 3 days after treatme & . & 4 & 4 & 3 & 3 & 3 & 3 & 3 & 2 & 1 & 1 & 1 & 1 & 0 & 8,192 \\
\hline 8.5 .50 & 12 days after treatm & & 4 & 4 & 3 & 3 & 2 & 2 & 2 & 2 & 1 & 1 & 1 & 1 & 0 & 8,192 \\
\hline
\end{tabular}


fractionation gave no results of any significance, and the same was the case with several other fractionating methods. It was not until the method of fractionating with $\mathrm{CO}_{2}$ was tried that any interesting results were obtained (Svartz and Schlossmann, 1953a, c). It was found by this method that there are at least three types of haemagglutinating factors. The factor that induces haemagglutination in lupus erythematosus, for instance, is not identical with the haemagglutinating factor in rheumatoid arthritis. Nevertheless, the different groups could not be clearly distinguished from one another by the $\mathrm{CO}_{2}$ method.

The method that has yielded the best results so far is fractionation by precipitation in cold. The blood serum from a patient suffering from rheumatoid arthritis, having first been inactivated and freed from heterophil agglutinins, is mixed with distilled water in the proportion $1: 14$ and allowed to stand in $+4^{\circ} \mathrm{C}$. for $48 \mathrm{hrs}$. A precipitate is then produced (Svartz and Schlossmann, 1953b, c). The same also applies to many other sera, but the extremely interesting circumstance could be observed that the cold precipitable fraction from rheumatoid arthritis is practically the only one that contains the haemagglutinating factor in question. In lupus erythematosus the haemagglutinating factor is left in the supernatant fluid and cannot be shown to exist in the precipitate (Table II).

TABLE II

HAEMAGGLUTINATION TEST PERFORMED WITH REDISSOLVED COLD PRECIPITATE FROM SERUM

\begin{tabular}{c|c|c}
\hline Clinical Diagnosis & $\begin{array}{c}\text { Haemagglutinating } \\
\text { Factor in Cold } \\
\text { Precipitate }\end{array}$ & $\begin{array}{c}\text { Haemagglutinating } \\
\text { Factor in Super- } \\
\text { natant Fluid }\end{array}$ \\
\hline Rheumatoid arthritis & + & $(+)$ \\
\hline $\begin{array}{l}\text { Other collagen diseases } \\
\text { (lupus erythematosus } \\
\text { disseminatus, sclero- } \\
\text { derma, dermatomyo- } \\
\text { sitis) }\end{array}$ & 0 & + \\
\hline
\end{tabular}

Our investigations show that there is in sera from patients with rheumatoid arthritis a substance that is, practically speaking, specific for that disease. It is a well-known fact that no biological reaction is absolutely specific for one disease only, but in regard to the reaction with the rheumatoid factor the exceptions are strikingly few. Thus, only in rare cases of other diseases, could an insignificant quantity of haemagglutinating factor be demonstrated in the cold precipitable fraction of serum. We are justified, then, in speaking of a specific rheumatoid arthritis test, giving positive results in $90-95$ per cent. of cases of the disease. It should be noted, however, that the test does not become positive until after $\frac{\text { D }}{7}$ the first 2 months of the disease.

We have sought to analyse the cold precipitate $\frac{5}{3}$ further by means of electrophoresis.

Different fractions of the cold precipitate have? been obtained with Carlson's modification of $\overrightarrow{\vec{F}}$ zone-electrophoresis (Carlson, 1954). For purposes $\frac{\overrightarrow{0}}{0}$ of comparison the electrophoretic diagram from $\frac{\square}{\circ}$ serum before treatment in cold is shown first. The $\frac{\bar{\sigma}}{\overline{0}}$ number of fractions examined is 25 (Fig. 1, opposite). $\widehat{\varnothing}$

As was to be expected from earlier investigations, the haemagglutinating factor was bound to the $s$ gamma-globulin fractions. Experiments were now $\overrightarrow{0}$ conducted with redissolved cold precipitate from the $\vec{\overrightarrow{ }}$ same serum as in the foregoing diagram (Fig. 2, opposite).

In proportion to the serum the sample is concentrated eight times. A high peak was obtained in $\vec{P}$ the $\gamma$-globulin, starting on the borderline between? $\beta$ - and $\gamma$-globulin. The fractions corresponding to $\overrightarrow{0}$ the peak in the diagram showed a clear and distinct haemagglutination reaction.

Certain observations indicate that the factor $\overrightarrow{\vec{c}}$ giving rise to the haemagglutination is not a normally existing $\gamma$-globulin. These investigations on the substance in question are not yet completed.

Svartz (1951) reported on some investigations \&ी ज़ the inhibition of the haemagglutination. It wo found that an inhibitor could be experimentalejy induced in rabbits by injecting into them serum or joint fluid from patients suffering from rheumatoid arthritis. Sera from rabbits injected with serum $\stackrel{\varnothing}{\mathscr{Q}}$ from blood-donors showed only a slight increase in $\underset{F}{\Rightarrow}$ the anti-haemagglutinating effect. During the past $\frac{3}{3}$ year studies have been made on the inhibitor of the $\vec{P}$ haemagglutination induced in rabbits by injections of the cold precipitable factor. The capacity for inhibition could be increased to about 1 in 1,000 by injecting the redissolved cold precipitable haem-음 agglutinating factor intravenously, showing that this. factor can act as an antigen. In addition, it was $ᄋ$ demonstrated that sera from normal rabbits were capable of inhibiting the haemagglutination up to a음 dilution of $1: 64$. The fact that normal rabbit $>$ serum sometimes has a rather pronounced capacity for inhibition must be considered when using a rabbit amboceptor serum for the haemagglutination test. It is necessary to use an amboceptor serum $\mathbb{O}^{\circ}$ with high haemolytic titre, viz. 1 in 4,000-6,000, స్ట so that the quantity of amboceptor serum used for the haemagglutination tests must not be high. It is interesting to note that normal human serum and horse serum absorbed with normal sheep cells did $\stackrel{\oplus}{+}$ not exhibit any anti-haemagglutinating capacity. 7 For these tests, $0.5 \mathrm{ml}$. human serum, resp. horse 


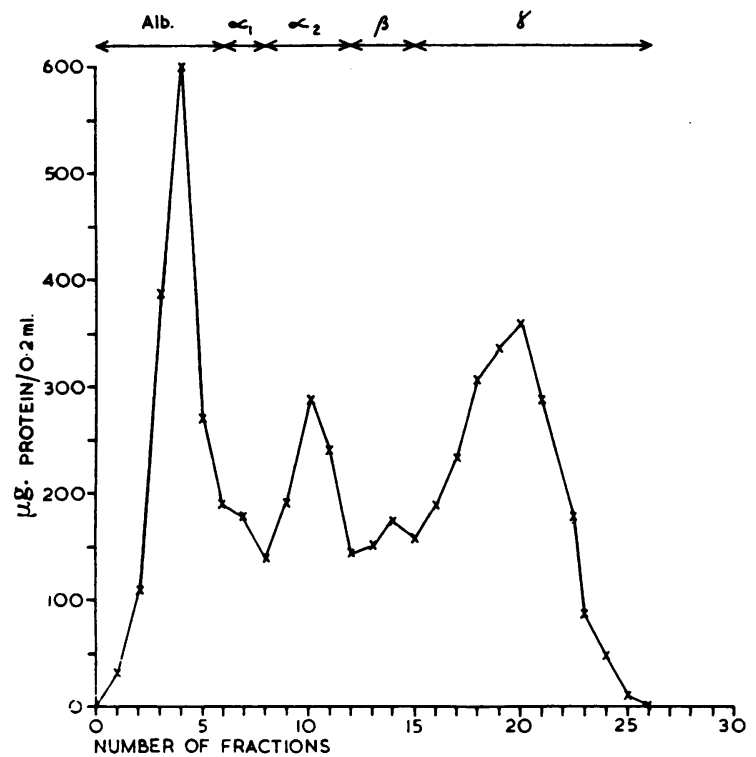

Fig. 1.-Zone electrophoresis on serum from rheumatoid arthritis. (Method of L. Carlsson.)

serum, and $0.5 \mathrm{ml}$. serum from patients suffering from rheumatoid arthritis were mixed, placed in a water bath at $37^{\circ} \mathrm{C}$. for $60 \mathrm{~min}$., and then tested for sheep-cell agglutination.

Another question of theoretical interest is which parts of the erythrocytes react with the amboceptor and the haemagglutinating factor. It seemed probable that the haemoglobin was of no importance in this respect. Large amounts of erythrocytes were haemolysed and the stroma washed with saline solution. The reaction performed with this stroma treated with amboceptor showed an agglutination.

Experiments have also been made to discover some method of creating experimentally the factor characteristic of rheumatoid arthritis. We shall here touch upon only one of these series.

Certain types of non-haemolytic cocci, the classification of which is not yet clear, were cultivated from the throats of patients with rheumatoid arthritis. Collagen tissue

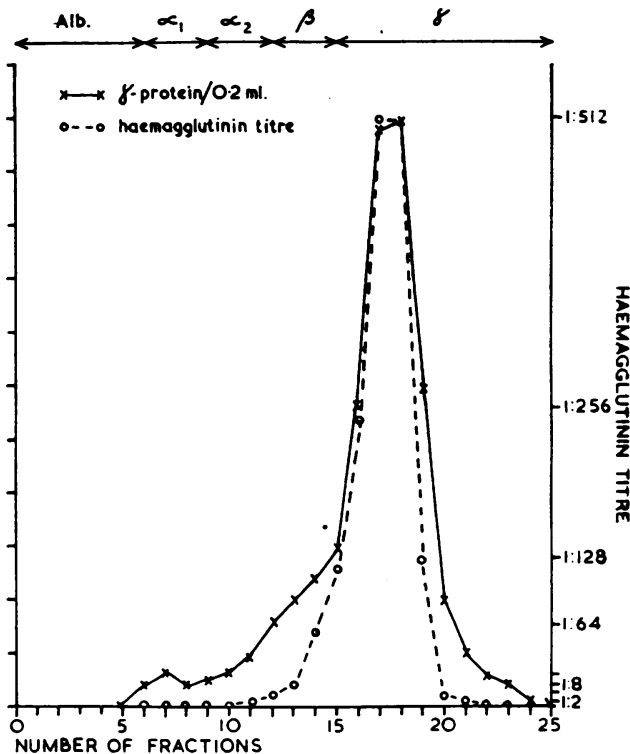

Fig. 2.-Zone electrophoresis on redissolved cold precipitate from the same rheumatoid arthritis serum as in Fig. 1, but concentrated eight times. Haemagglutination test made with the various fractions obtained by zone electrophoresis.

(from tendons and peri-articular tissue) was used as the culture medium. The bacteria having been allowed to grow for some time on the substratum, they and other particles in the culture were removed by centrifugation. As from serum, cold precipitate was obtained from the culture fluid. The redissolved cold precipitable substance showed a haemagglutination reaction of the same type as precipitate from rheumatoid arthritis serum (Table III).

Our observations show that the haemagglutinating factor is induced by enzymes, which are formed by the bacteria. It is obvious that several types of bacteria have the capacity to form the enzyme here in question, but in this connexion it is interesting to note that haemolytic streptococci and staphylococci have not shown the phenomenon in question.

Our investigations seem to indicate that the specific haemagglutinating factor in rheumatoid arthritis is induced by enzymatic influence upon the collagen tissue in the organism.

TABLE III

HAEMAGGLUTINATION PRODUCED BY REDISSOLVED COLD PRECIPITATE FROM BACTERIA-FREE FILTRATES OBTAINED FROM CULTURES OF NON-HAEMOLYTIC COCCI

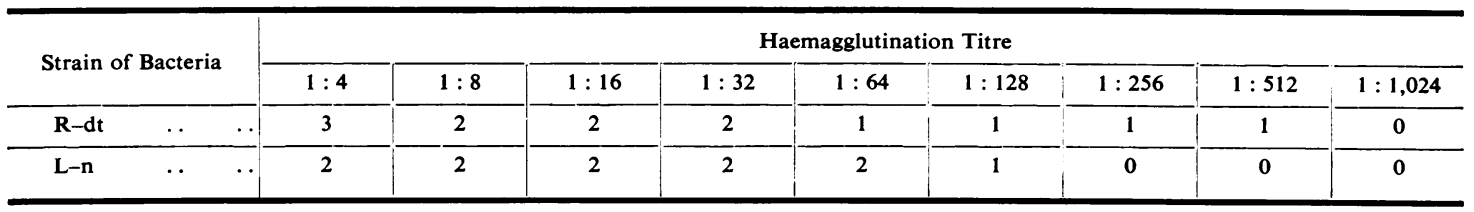




\section{Summary}

A substance characteristic of rheumatoid arthritis exists in the blood and synovial fluid of patients with that disease. This substance is able to agglutinate sensitized sheep erythrocytes.

This haemagglutinating factor can be demonstrated in cold precipitate from blood serum, but only in exceptional cases do cold precipitates from sera other than rheumatoid arthritis give rise to a slight haemagglutination.

The haemagglutinating factor is found in the $\gamma$-globulin fraction of serum, but apparently it is neither a pure $\gamma$-globulin nor a normal one.

Rabbit serum, but not normal human serum or horse serum, usually contains a factor inhibiting the haemagglutinating reaction.

The stroma of erythrocytes and not the haemoglobin reacts with the amboceptor in sensitization.

A haemagglutinating factor with the same properties as the serum of rheumatoid arthritis can be created experimentally by culturing certain types of bacteria (non-haemolytic cocci) on collagen tissue. In these experiments the haemagglutinating factor could be recovered from the bacteria-free culture fluid. The results indicate that enzymes produced by the bacteria give rise to the haemagglutinating substance through their effect on the collagen tissue.

To judge from the investigations so far carried out, it is probable that the specific haemagglutinating substance in serum taken from patients with rheumatoid arthritis is formed as a result of enzymatic influence upon the collagen tissue in the organism.

\section{REFERENCES}

Carlson, L. (1954). Acta chem. scand., 8, 510

Meyer, K. (1922). Z. Immunität., 34, 229.

Rose, H. M., Ragan, C., Pearce, E., and Lipman, M. O. (1948), Proc. Soc. exp. Biol., 68, 1.

Svartz, N. (1950). Acta med. scand., Suppl. 246, p. 240

- (1951). Ibid., Suppl. 259 (Proc. I Int. Congr. intern. Med., Paris, 1950), p. 18.

(1952). In American Rheumatism Association: "Rheumatic Diseases (Proc. VII Int. Congr. Rheum. Dis., 1949)”, pp. 342 and 360. Saunders, Philadelphia.

and Schlossmann, K. (1950). Annals of the Rheumatic Diseases, 9, 377.

(1952). Acta med. scand., 142, 420.

$二, \quad$ (1953a). Ibid., 145, 216.
(1953b). Ibid., 146, 313.
Schweiz. med. Wschr., 83, 782.

二, - (1953a). Ibid., 145, 216. (1953b). Ibid., 146, 313. Wschr., 83, 782.

Waaler, E. (1940). Acta path. microbiol. scand., 17, 172.

Le facteur hémagglutinant dans le sérum chez les malades atteints de la polyarthrite chronique évolutive

\section{RÉSUMÉ}

Dans la polyarthrite chronique évolutive (arthrite rhumatoide) se trouve, dans le sang et dans le liquide synovial, une substance qui est caractéristique pour cette $\mathrm{J}$ maladie. Cette substance a la faculté d'agglutiner les globules rouges sensibilisés du mouton.

Le facteur hémagglutinant s'attache à la fraction de $\exists$ globuline $\gamma$ du sérum, mais il ne s'agit ni d'un $\gamma$-globuline normal ni d'un globuline pur.

Le sérum des lapins contient généralement un facteur $\vec{F}$ qui empêche la réaction de l'hémagglutination. Le $\stackrel{\mathcal{O}}{\stackrel{O}{O}}$ sérum de l'homme ou celui du cheval ne contiennent $\bar{O}$ pas ce facteur.

C'est le stroma des globules rouges et non l'hémo- $\overline{\bar{\omega}}$ globine qui réagit avec l'ambocepteur dans la sensibilisa- $\overparen{\nabla}$ tion.

Expérimentalement, on peut provoquer un facteur \% hémagglutinant possédant les mêmes propriétés que le facteur du sérum dans l'arthrite chronique évolutive. $\stackrel{\circ}{\circ}$ Cela s'est montré possible, entre autres, en cultivant certaines bactéries sur le tissu conjonctif. Le facteur $\vec{\omega}$ hémagglutinant, pouvait dans ces essais, être constaté $\stackrel{\Omega}{\circ}$ dans le liquide de culture dégagé de bactéries. Le résultat de ces expériences montre que c'est des enzymes produites ? par les bactéries qui provoquent le facteur hémagglutinant, $\vec{A}$ par son action sur le tissu conjonctif.

A en juger par les recherches déjà faites, il est vrai- $\overrightarrow{0}$ semblable que la substance spécifique hémagglutinante $\stackrel{\oplus}{-}$ du sérum chez les malades atteints d'arthrite chronique 0 évolutive, est formée par l'action des enzymes sur le tissu conjonctif de l'organisme.

\section{El factor hemoaglutinante en el suero de enfermos con artritis reumática}

\section{RESUMEN}

En el artritis reumática crónica hay en la sangre y el líquido sinovial una substancia que es característica esta enfermedad. Tiene el poder esta substancia de aglutinar los hematíes sensibilizados de oveja.

Pertenece el factor hemoaglutinante a la fracción de $\frac{\mathrm{Q}}{\mathbb{Q}}$ $\gamma$-globulina del suero, pero no es ni una $\gamma$-globulina $\varrho$ pura ni una $\gamma$-globulina regular.

En el suero del conejo hay generalmente un factor que 3 puede impedir la reacción de hemoaglutinación. En el suero del hombre o del caballo no existe este factor.: Es el estroma y no la hemoglobina de los glóbulos rojos: que reacciona con el amboceptor en la sensibilización.

Se puede producir experimentalmente un factor? hemoaglutinante con las mismas propiedades que el factor de suero de artritis reumática crónica. Se ha. podido hacer por ejemplo por cultivar ciertas bacteriaso̊ en tejido colageno. En estos experimentos se haร demostrado el factor hemoaglutinante en el líquido de cultivo descargado de bacterias. Muestran estas investigaciones que son fermentos producidos por las bacterias $>$ que produce el factor hemoaglutinante por su influenciao sobre el tejido conjunctivo.

Según las investigaciones que se han hecho hasta ahora parece probable que se forma la substancia hemoaglutinante específica en el suero de enfermos cono artritis reumática crónica por influencia de fermentos sobre el tejido conjunctivo del organismo. 